\title{
Justification of an effective method of potatoes harvesting
}

\author{
T. S. Baybulatov ${ }^{1}$, B. I. Khamkhoev ${ }^{2}, K . M$. Uzhakhov ${ }^{2}$, and $A . K h$. Tsechoeva ${ }^{2}$ \\ ${ }^{1}$ Dagestan Institute for Advanced Training of Personnel of the Agro-Industrial Complex, \\ Makhachkala, Russia. \\ ${ }^{2}$ Ingush State University», Magas, Russia.
}

\begin{abstract}
It is proved that high-quality potato harvesting is one of the most important technological operations that contributes to improving the safety of tubers during their storage. It is established that the digging working body on the potato harvester has low agrotechnical performance parameters, which directly affect the productivity, quality of harvested tubers, work and resistivity of the harvesting unit. A bar digging working body is proposed, the use of which allows to reduce the volume of soil supplied to elevators, which improves the separation of pile, and the tubers after the passage of the unit are not covered with soil coming off the conveyor. In addition, the rod working body allows the harvesting machine to work within the limits of agrotechnical requirements, eliminating damages and losses of tubers, improving the aggregate composition of the soil, as well as reducing its specific traction resistance and increasing productivity.
\end{abstract}

\section{Introduction}

Currently, there is a growing demand for high - quality potatoes-both for sale through the retail chain and for industrial processing. The technology of potato production includes a number of technological operations, such as tillage, fertilization, harvesting, and others [5, $6,9,10,11,17,19]$. The effectiveness of these operations as a whole will determine the effectiveness of the entire technology. At the same time, the energy and quality parameters of any technological operation are directly dependent on the design and technological parameters of technical means of its conducting and their working bodies, which makes their further theoretical and experimental improvement relevant [7, 8, 12-15, 18, 22, 24].

The quality of the potato harvest depends largely on the quality of the potato harvesters, established soil and climatic conditions, and other factors [2, 16, 20, 21, 23, 25]. Improving the quality of potato harvesting is the most important factor determining its safety. The use of even the most advanced storage methods cannot guarantee the crop safety, if its initial quality is low. A significant impact on the safety is caused by mechanical damage to potatoes, which were received during the harvesting process.

As you know, the digging working body installed on the harvesting machine is designed to perform the following technological process: cutting the tuberous beds from below with a separation on the sides, crumbling and evenly feeding the pile with minimal losses and damages of tubers to the elevator for separation. 
The disadvantages of the digging working bodies produced by the industry are low agrotechnical performance parameters, and the quality and quantity of harvested tubers, productivity, and specific resistance of the harvesting machine directly depend on them. Attempts to use active ploughshares, some of which have an adjustable oscillation frequency, also do not give high results, which leads to the damage of tubers, an increase in energy consumption and the need to set the digging depth by $2-4 \mathrm{~cm}$ more than the depth of tubers $[1,20,27,28]$.

\section{Materials and methods}

Experimental studies were conducted in order to justify the effectiveness of use of a rod digging working body (experience) in comparison with conventional digging bodies (control) when harvesting potatoes of the varieties Volzhanin and Lorkh, in the conditions of the peasant farm "Khashagulgov A.T." of the Republic of Ingushetia.

\section{Results and discussions}

An important characteristic of digging bodies is the reduction of damage to tubers during harvesting. The methods of harvesting used in farms have a number of disadvantages: large losses of backfilled tubers after insufficient separation by working bodies; low productivity parameters of harvesting and transport machines; workers on selection - high labor costs; a sharp decrease in the quality of work of all working bodies at high harvesting speeds [4].

The essence of the proposed technology of potato harvesting is as follows: bar ploughshares are installed on the $\mathrm{KTN}-2 \mathrm{~B}$ potato digger, instead of standard digging ploughshares [16], the design of which allows you to change the parameters of the incoming tuber layer and significantly reduce the volume of the pile with blocks and lumps falling on separating elevators (Fig. 1). As a result, damages and losses of tubers are significantly reduced, including due to not backfilling them with soil $[2,3,20]$.

The results of experimental studies have shown that the digging working body can significantly reduce the total amount of pile fed to elevators, which significantly reduces the damage of potato tubers. The working body allows the harvesting machine to work within the limits of agrotechnical requirements, eliminating the loss of tubers due to backfilling and breaking up the soil formation on the sides. It allows us to crumble efficiently and evenly feed the soil formation without losses and damages, reduce the resistivity and increase the productivity of the unit due to the bar surface and the width of the digging working body.

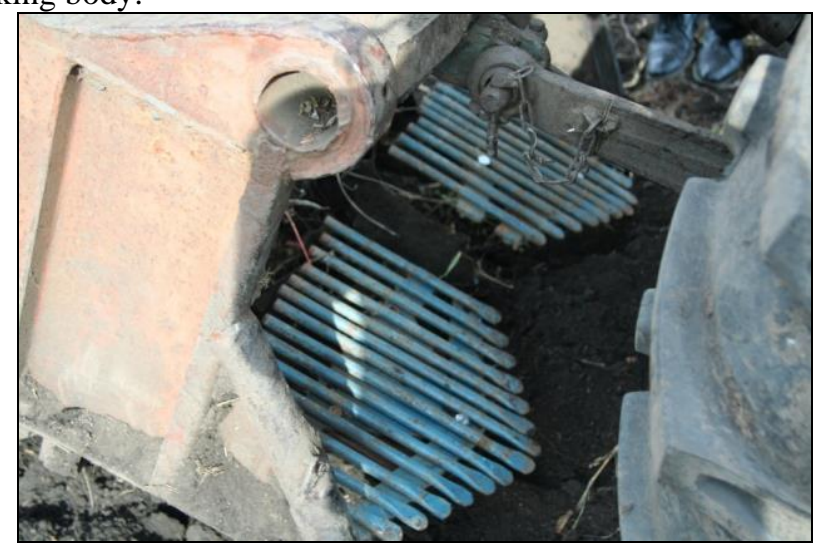

Fig. 1. General view of the bar digging working body 
The results of comparative experimental studies of the use of a bar digging working body in comparison with the standard one, according to the number of excavated and backfilled potato tubers, are presented in Table 1.

Table 1. The number of excavated and backfilled potato tubers under various harvesting technologies, $\mathrm{pcs} / \mathrm{m}$.

\begin{tabular}{|l|c|c|c|c|c|c|c|c|}
\hline The number of & \multicolumn{7}{c|}{ Control type } & \multicolumn{5}{c|}{ Experimental type } \\
\cline { 2 - 8 } $\begin{array}{c}\text { potatoes, } \\
\text { pcs/m. }\end{array}$ & 1 & 2 & 3 & $\begin{array}{c}\text { Average } \\
\text { value }\end{array}$ & 1 & 2 & 3 & $\begin{array}{c}\text { Average } \\
\text { value }\end{array}$ \\
\hline \multicolumn{8}{|c|}{ The variety Volzhanin } \\
\hline excavated & 90 & 65 & 92 & 82,3 & 136 & 151 & 96 & 127,6 \\
\hline backfilled & 24 & 26 & 23 & 24,3 & 34 & 11 & 4 & 16,3 \\
\hline \multicolumn{8}{|c|}{ The variety Lorkh } \\
\hline excavated & 108 & 86 & 94 & 96 & 128 & 164 & 112 & 134,6 \\
\hline buried & 23 & 20 & 28 & 23,6 & 28 & 12 & 8 & 16 \\
\hline
\end{tabular}

$1,2,3$-repeatability of experience

Control version-MTZ-80+ KTN-2B with conventional ploughshares;

The prototype version is MTZ-80+ KTN-2B with bar ploughshares.

As can be seen from Table 1, the average number of excavated potato tubers in the Volzhanin variety in the control version was $82.3 \mathrm{pcs} . / \mathrm{m}$, when in the experimental version this value was $127.6 \mathrm{pcs} . / \mathrm{m}$. If the number of backfilled tubers in the control was $23.0 \%$, in the experiment the number of these tubers was $12.1 \%$ of the total number of tubers per one linear meter of a row of potatoes.

In the Lorch variety, the average number of excavated tubers in the control variant was $96.0 \mathrm{pcs} / \mathrm{m}$, when backfilled with soil was $23.6 \mathrm{pcs} / \mathrm{m}$, and in the experimental version, the average number of excavated tubers was $89.3 \%$, and backfilled-10.7\%.

In addition, one of the main agrotechnological parameters for assessing the total composition of the soil is the degree of grinding, which is determined by the percentage of fractions of the following sizes: $2.5 \ldots 5.0 ; 5.0 \ldots 10$ and more than $10 \mathrm{~cm}$.

The use of a potato digger with bar digging working bodies contributed to the improvement of the aggregate composition of the soil, which is explained by the fact that the process of cutting and feeding the soil layer by the digging working body is carried out without unloading by reducing the total amount of heaps and lumps fed to the separator and by sifting the heaps through the gaps between bars $[2,3]$.

The results of the experiments and their analysis showed that the aggregate composition of the soil when harvesting potatoes in the control and experimental versions have different values of the quantitative composition of the soil fractions (Fig. 2).

When using the technological process of potato harvesting recommended by us, the average total content of the above-mentioned fractions in the soil structure was $6.6 \mathrm{pcs} / \mathrm{m}^{2}$, which is $40.0 \mathrm{pcs} / \mathrm{m}^{2}$ less than the number of the same fractions when using the existing technological process of potato harvesting $[2,3]$.

The data of Figure 2 show that the use of the recommended technological process of potato harvesting with bar digging working bodies contributed to the improvement of the aggregate composition of the soil: the number of lumps with a size of $2.5 \ldots 5 \mathrm{~cm}$ decreased by $23.3 \mathrm{pcs} / \mathrm{m}^{2}$, soil particles with a size of $5 \ldots 10 \mathrm{~cm}$ decreased by $10.0 \mathrm{pcs} / \mathrm{m}^{2}$, and fractions of 10 and more $\mathrm{cm}$ were generally absent. 


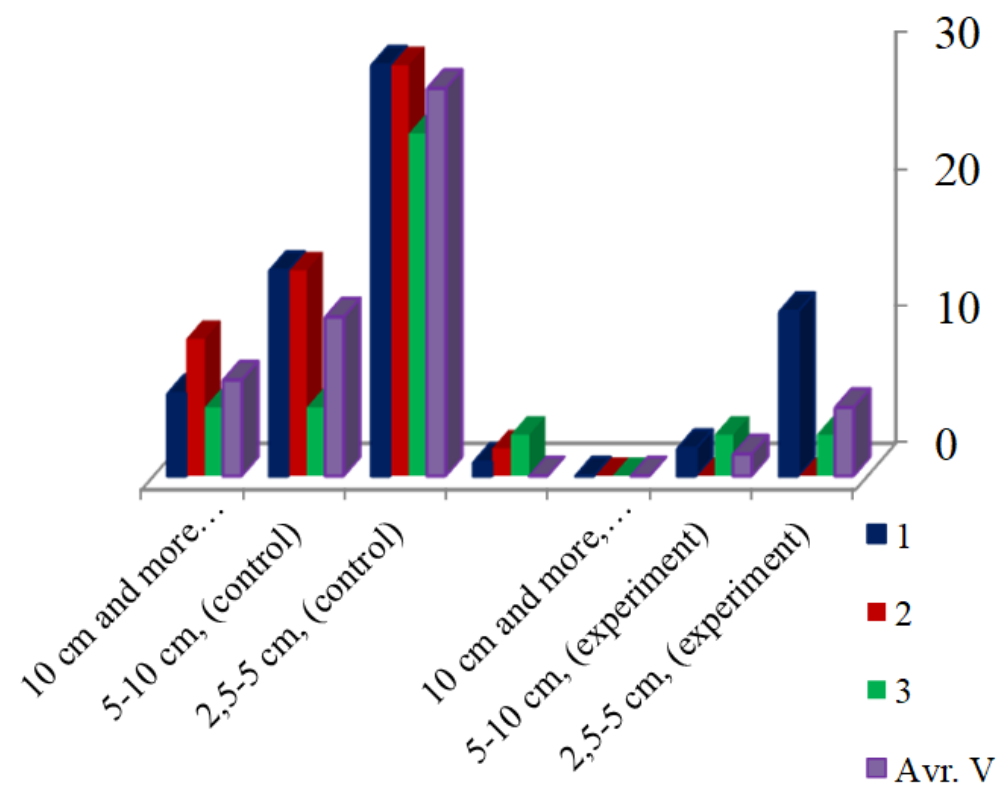

$1,2,3$ - repeatability of experience

Fig. 2. Aggregate composition of soil depending on the method of harvesting potatoes, $\mathrm{pcs} / \mathrm{m}^{2}$

\section{Conclusions}

The technology of potato harvesting proposed by us provides for the use of a bar digging working body, which helps to reduce losses and damages of tubers behind the harvesting machine, as well as to improve the aggregate composition of the soil, reduce the traction resistance of the unit and increase its productivity.

It was found that the use of a bar digging working body contributed to improving the quality of potato harvesting: the average number of excavated potato tubers in the Volzhanin variety in the control version was $82.3 \mathrm{pcs} / \mathrm{m}$, when in the experimental version this value was $127.6 \mathrm{pcs} / \mathrm{m}$. If the number of filled tubers in the control was $23.0 \%$, in the experiment the number of these tubers was $12.1 \%$ of the total number of tubers per one linear meter of a row of potatoes. In the Lorkh variety, the same values, in the control version-96.0 pcs $/ \mathrm{m}$, when backfilled with soil was $23.6 \mathrm{pcs} / \mathrm{m}$, and in the experimental version, the average number of excavated tubers was $89.3 \%$, and backfilled- $10.7 \%$.

The use of bar digging working bodies contributed to the improvement of the aggregate composition of the soil, namely: the number of lumps with a size of $2.5 \ldots 5 \mathrm{~cm}$ decreased by $23.3 \mathrm{pcs} / \mathrm{m}^{2}$, the size of $5 \ldots 10 \mathrm{~cm}$ decreased by $10.0 \mathrm{pcs} / \mathrm{m}^{2}$, and fractions of $10 \mathrm{~cm}$ or more were generally absent.

\section{References}

1. Aushev M.Kh., Khamkhoev B.I., Khamkhoev Yu.I. The potato digger for potatoes harvesting in the conditions of the South of Russia, Materials of All-Russian ScientificPractical Conference «University education and science», Magas, 2015.

2. Baybulatov N.S., Khabibov S.R., Khamkhoev B.I. Improvement of the technological process of potato harvesting, Problems of regional AIC development, Makhachkala, 
2019.-№1(37). -P.11-14.

3. Baybulatov N.S., Baybulatov T. S. Aushev M.Kh., Khamkhoev B.I., Tsechoeva A.Kh. Results of researches of a potato digger with bar digging working bodies, IOP Conf. Series, «International Conference on Global Technological Trends in Agriculture», Omsk, West Siberia, Russian Federation, 4-5 July 2020, Volume 624. https://iopscience.iop.org/journal/1755-1315

4. Baybulatov T.S., Aushev M.Kh., Khamkhoev B.I. Results of researches of a potato digger with bar digging working bodies, Problems of the development of the agroindustrial complex of the region, Makhachkala, 2019, №3(39), P.32-36.

5. S. V. Belousov, D. A. Filippov, Introduction of fertilizers to the field surface, E3S Web of Conferences, 193,01011 (2020).

6. S. V. Belousov, Y. V. Khanin, V. V. Zhadko S.V., Methods and means of concentrated fertilizers application, IOP Conf. Series: Materials Science and Engineering, 971 (2020) 052050 .

7. S. V. Belousov, E. E. Samurganov, A. I. Rodionenko, Theoretical justification of the type of a flat-cutting working body of a ploughshare, IOP Conf. Series: Materials Science and Engineering709 (2020) 033100.

8. S. V. Belousov, E. A. Saprykin, I. S. Karmazin, Explanation of the angle of sharpening of a plough cutting working body, E3S Web of Conferences, 126, 00025 (2019).

9. A. E. Bogus, A. D. Kuzmenko, Substantiation of the technological scheme of pneumatic grain seeder of subsurface dense sowing, E3S Web of Conferences, 126, 00040 (2019).

10. S. M. Borisova, S. K. Papusha, V. K. Papusha A device for harvesting and utilization of non-grain part of crop and fertilization, IOP Conf. Series: Materials Science and Engineering971 (2020) 052061.

11. V. Vinevskiy, E. Trubilin, S. Papusha, A. Ognyanik E. I. Mechanical - Technological Basics Of Machine Harvesting Of Tobacco Leaves, Research journal of pharmaceutical biological and chemical sciences, 2018, № 5, P.1163-1176.

12. V. Konovalov, S. Konovalov, V. Igumnova Constructive-technological diagram of the rotary-string cultivator and the definition of its main parameters, E3S Web of Conferences 126, 00039 (2019).

13. V. Konovalov, S. Konovalov, V. Igumnova Analytical substantiation of constructive parameters of rotating field board of plow's body, E3S Web of Conferences, 126, 00038 (2019).

14. Konovalov V. V. Konovalov, S. Konovalov, V. Igumnova Analytical substantiation of constructive parameters of rotating field board of plow's body, E3S Web of Conferences 126, 00038 (2019).

15. Konovalov V. Justification of design parameters of a disk working body with a changing radius of curvature, E3S Web of Conferences 193, 01014 (2020).

16. Levshin A.G. and et al. Patent on useful model №165720. Digging working body, Published 10.11.2016. Bul. №31.

17. G. G. Maslov, E. M. Yudina, A. S. Serguntsov, R. O. Evglevsky Rational System Of Multifunctional Aggregates For Mechanization Of Plant Growing, Research journal of pharmaceutical biological and chemical sciences, 2018, № 9, P.1177-1185.

18. S. K.Papusha, A. E.Bogus, V.I. Konovalov Interaction of rotary working body of roller type with the object of processing, MATEC Web of Conferences (ICMTMTE 2018) 224, 05007 (2018).

19. G. G. Maslov, E. M. Yudina, D. A. Ushakov, G. E. Samurganov Modernization of engineering support of crop cultivation, IOP Conf. Series: Earth and Environmental Science624 (2021) 012107. 
20. Maslov, G. G., Trubilin, E. I., \&Truflyak, E. V. (2016). Parameters optimization for multifunctional aggregates in plant growing mechanization. Research Journal of Pharmaceutical, Biological and Chemical Sciences, 7(3), 1919-1926.

21. S. K. Papusha, D. A. Kotov, V. V. Zhadko Technological features of a combined soil processing machine and sprayer, E3S Web of Conferences 193,01026 (2020).

22. S.K. Papusha, S. V. Belousov, A. E. Bogus, V. I. Konovalov Theoretical studies of the tobacco stalk interaction with the leaf-separating unit, International Journal of Applied Engineering Research, 11(8), 5610-5613.

23. A. Serguntsov, V. Serguntsova Optimization of parameters and operating modes of the rotary working body for harrowing agricultural crops, E3S Web of Conferences 193,01021 (2020).

24. A. Serguntsov, V. Serguntsova, N. Malashikhin Operational parameters and modes of rotary working body for harrowing crops, E3S Web of Conferences 126,00023 (2019).

25. V. V. Tsybulevsky, G. G. Maslov Decision theory for choosing the best machine from alternative options, IOP Conf. Series: Earth and Environmental Science 677 (2021) 032097.

26. Khamkhoev B.I. Researches and justification of the working parameters of the KTN-2B potato digger in the foothills of the North Caucasus, Materials of the International scientific conference of students, postgraduates and young scientists. "Perspektiva2015". Volume IV, Nalchik, 2015, P. 77-79.

27. Khamkhoev B.I. Study of the working parameters of the digging working bodies of harvesting machines, Proceedings of scientific papers of the Ingush State University, No. 13, Magas, 2016.

28. Khamkhoev B.I., Khamkhoeva Z.Kh., Kodzoev I.B. Research and improvement of the working parameters of the potato digger in the conditions of the foothills of the North Caucasus, Materials of the international scientific conference of students, postgraduates and young scientists "Perspektiva-2018". Volume I, Nalchik. 2018. 